\title{
THE EFFECTIVENESS OF MUSIC THERAPY IN REDUCING ANXIETY IN THIRD TRIMESTER OF PREGNANCY
}

\author{
Eti Salafas $^{1)}$, Puji Lestari' ${ }^{2)}$,Moneca Diah Listiyaningsih ${ }^{3)}$ \\ Email: etisalafas.unw@gmail.com \\ ${ }^{1,2,3}$ Prodi D3 Kebidanan Fakultas Ilmu Kesehatan Universitas Ngudi Waluyo \\ Jl. Diponegoro 186 Kabupaten Semarang
}

Article Information

Received:

September 14, 2019

Revised:

December 20, 2019

Accepted:

January 19, 2020

Available online:

January 23, 2020

\begin{abstract}
The average anxiety experienced by third-trimester pregnant women is higher than the first and second trimester. Anxiety increases as the gestational age get older. If this condition had not to handle, it could impact on pregnancy and during labour. Efforts to overcome anxiety can be made with music therapy. This therapy is therapy without drugs by playing music to pregnant women. Song rhythm, harmony, and beat 60 beats per minute can make the mother calm. The purpose of this study was to determine the level of anxiety of pregnant women before and after the intervention, then analyze the effectiveness of music therapy in reducing anxiety levels. The method used is a quasi-experiment. The population in this study was third-trimester pregnant women in the Ambarawa Puskesmas area with samples taken by purposive sampling of 30 respondents. Data collection carried out in August 2019. The data not normally distributed, so the analysis carried out using the Wilcoxon test with the results that there were different levels of anxiety before and after treatment with music therapy $(\mathrm{p}=0.001)$. The average anxiety score after being given music therapy dropped to 4.47 from 9.53 , although it was still in the mild anxiety category. It can be concluded that music therapy is effective in reducing the anxiety level of pregnant women in the third trimester. Music therapy recommended being applied in the management of anxiety on pregnant women in the third trimester.
\end{abstract}

Keywords: Anxiety Level, Music Therapy, Third-trimester, Pregnant Women

\section{Introduction}

Pregnancy is a process of conception, nidation and implantation, where the pregnancy lasts for 280 days. Since the meeting of sperm and ovum, the mother's body adapts to physiological and psychological changes. Physiological changes that occur in the form of cardiovascular, endocrine, digestive, urinary, and reproductive changes. This change creates discomfort for these pregnant women. Despite the emergence of this discomfort, the appearance can vary between pregnant women.
Physiological discomforts that appear during pregnancy, such as frequent urination, low back pain, nausea, vomiting and others. ${ }^{[1]}$

Adaptations in the form of psychological changes that occur early in pregnancy. In the early trimester, the mother feels less sure of the pregnancy, and they tend to look for signs and symptoms that make sure the existence of pregnancy. Enlargement of the uterus makes the body shape change; most mothers feel strange with their body. Pregnant women can be more sensitive, 
need more attention, need more support because of increased anxiety regarding the discomfort experienced. Moreover, the increasing age of pregnancy before delivery. Some anxiety experienced by the mother increases due to several factors, namely knowledge and understanding of the physiological changes in pregnancy, previous pregnancy experiences, age of the mother, environment and others that are sometimes not realized by the mother what is the cause. ${ }^{[2]}$

One hundred seven thousand or about $28.7 \%$ of pregnant women in Indonesia experience anxiety regarding childbirth $^{[3]}$. It usually occurs in the third trimester or other words, the first and the second trimester have lower anxiety than the third trimester. If the anxiety level was categorized, there were $47.2 \%$ pregnant women with moderate and severe anxiety ${ }^{[4]}$.All events that occur during the pregnancy period significantly affect the continuity of pregnancy and childbirth. Anxiety in pregnant women must be overcome; if left unchecked, it will give an adverse impact on pregnancy and childbirth later. Childbirth can be more painful because the mother is anxious, so the natural oxytocin hormone, which plays an essential role in labour is hampered and makes the labour phase long.

A study that has been done to find out the effectiveness of Hypno-EFT and yoga breathing shows that Hypno-EFT and yoga breathing were very effective in reducing the anxiety of pregnant women $^{[5]}$. Treatment other than Hypno EFT and breathing yoga is to use music therapy. This therapy is cheap and easy to use. Almost everyone likes music, and the body is very responsive to the music it hears. Music is an auditory stimulus, organized consisting of a composition of tones, rhythms, a fusion of tones, timbre, form and style. ${ }^{[6]}$

The choice of the type of music used for therapy needs to be considered because the body will respond according to the music it hears. The type of music that can help relaxation and control anxiety is a type of relaxing music with a tempo of 60 beats/minute. ${ }^{[7,8]}$ Music that played can make someone calm. The mind is allowed to flow to the beat, remembering happy things, dreaming of a dream, or even describing the problem ${ }^{[7]}$.Music enters through the ear and stimulates the hypothalamus to produce dopamine and reduces the hormone cortisol. So that the mother feels calm and happy, this condition, if maintained, will improve physical, psychological, social and spiritual health ${ }^{[6]}$. The existence of music as therapy needs to be investigated to determine the effectiveness of music therapy in reducing anxiety levels in third-trimester pregnant women.

\section{Method}

This study used a quasi-experiment on samples of pregnant women in the third trimester at Ambarawa Public Health Centre with a total of 30 people who did not have hearing loss. The first step was to measure anxiety before treatment; the second provided relaxation music therapy with a beat of $60 \mathrm{bit} / \mathrm{minute}$ for 15 minutes, then anxiety was measured after treatment, the third analyzes the effectiveness of music therapy.

Data collection used HARS (Hamilton Rating Scale for Anxiety). The anxiety before and after treatment analyzed with descriptive analysis. The effectiveness of music therapy was analyzed by the Wilcoxon test because the data were not normally distributed.

\section{Results and Discussion}

Table 1 Anxiety Level of Pregnant women before being given Music Therapy

\begin{tabular}{lllll}
\hline $\begin{array}{c}\text { Anxiety } \\
\text { Score }\end{array}$ & Category & $\mathbf{f}$ & $\mathbf{\%}$ & $\begin{array}{c}\text { Anxiety } \\
\text { Mean } \\
\text { Score }\end{array}$ \\
\hline 0 & $\begin{array}{l}\text { Without } \\
\text { Anxiety }\end{array}$ & 2 & 6.66 & \\
$1-13$ & $\begin{array}{l}\text { Mild } \\
\text { Anxiety }\end{array}$ & 24 & 80 & 9.53 \\
$14-26$ & $\begin{array}{l}\text { Moderate } \\
\text { Anxiety } \\
\text { Total }\end{array}$ & 4 & 13.33 & $\mathbf{3 0}$ \\
\hline
\end{tabular}


The category of convincing mothers before being given music therapy was the most widely agreed to by mild anxiety of 24 respondents (80\%), while the respondents without anxiety were two respondents. The average anxiety score obtained is 9.53 , which classified as a mild anxiety category.

Anxiety in pregnant women is a response to physiological changes that occur due to the process of pregnancy. The anxiety occurs because of the alleged existence of a threat and endangers to the pregnancy. Each pregnant woman has a different level of anxiety, depending on how she understands and interpret the pregnancy. Several factors related to maternal anxiety are husband support, maternal readiness, prior pregnancy knowledge and experience. ${ }^{[9]}$

Most anxieties in pregnant women found on the first pregnancy (primigravida). In this study, primigravida mothers amounted to five respondents who all experienced mild anxiety before being given music therapy. For primigravida, change in self is the first experience that can increase anxiety.

Anxiety increases with gestational age, especially near childbirth time. The final months of pregnancy are a period of waiting and being alert. The birth of a baby from pregnancy is highly anticipated. The older the pregnancy, the anxiety arises if at any time give birth. Mothers are more aware of the signs and symptoms of labour. Mothers begin to worry about the physical hazards that may occur during childbirth [1]. Fear of congenital malformation, pain during labour, complications such as bleeding, to fear of death of the baby or herself.

Anxiety, if not appropriately addressed, it could affect the increase in labour pain, tense muscles and can cause prolonged latent or active phase. ${ }^{[6]}$

Table2 Anxiety Level of Pregnant women After being given Music Therapy

\begin{tabular}{lllll}
\hline $\begin{array}{c}\text { Anxiety } \\
\text { Score }\end{array}$ & Category & F & \% & $\begin{array}{c}\text { Anxiety } \\
\text { Mean } \\
\text { Score }\end{array}$ \\
\hline 0 & Without & 8 & 26.7 & \\
$1-13$ & $\begin{array}{l}\text { Anxiety } \\
\text { Mild Anxiety }\end{array}$ & 20 & 66.6 & 4.47 \\
$14-26$ & $\begin{array}{l}\text { Moderate } \\
\text { Anxiety } \\
\text { Total }\end{array}$ & 2 & 6.7 & \\
& & $\mathbf{3 0}$ & $\mathbf{1 0 0}$ & \\
\hline
\end{tabular}

Most pregnant women in the third trimester after being given music therapy were had mild anxiety, 20 respondents $(66.6 \%)$, while the least were had moderate anxiety. The average anxiety score after being given music therapy dropped to 4.47 from 9.53, although it was still in the mild anxiety category.

Like previous studies, the results of this study also found that pregnant women in the third trimester had anxiety. The anxiety that appears can affect the physical mother due to stress, as well as the fetus will interfere with blood circulation to the fetus. So that anxiety is not sustainable, then given the intervention in the form of distraction and focus on something other stimuli such as providing stimulus in the form of music, a therapy without drugs.

Anxiety experienced by respondents experienced a decrease after getting music therapy. Therapy was given to respondents in the form of passive music therapy (listening to music). Music was listened to pregnant women and entered through the ears, spreads throughout the brain and provides stimulation to the hypothalamus so that the hormone cortisol decreases, which makes the mother calmer. Thus music could make mothers happier, more comfortable, less pain and reduce anxiety before labour ${ }^{[2]}$. In primigravida, this therapy can reduce anxiety. ${ }^{[3]} \mathrm{In}$ a study, anxiety in pregnant women could be reduced by giving classical music therapy; this was indicated a decrease in anxiety in the moderate category from $55 \%$ of respondents to $15 \%$ (decreased by $40 \%$ ). There was a significant difference between before and after given classical music therapy $(p=0.005)$. (4) There was 
a decrease in the average level of anxiety in primigravida. In group 1 , from 31.92 (pretest) decrease to 24.69 (posttest), and in the group 2 from 34.54 (pretest) decrease to 25 (posttest) with a p-value < 0.05 . There was an increase in average $\beta$ endorphin levels in the group 1 from 53.63 (pretest) to 63.24 (posttest), and group 2 from 48.55 (pretest) to 64.9 (posttest) with p-value $<0.0 .^{[5]}$

Music can reduce muscle tension, blood pressure and heart rate so that the body becomes stable and the fetus becomes comfortable in the womb ${ }^{[3]}$. Indirectly, it influences the bonding of mother and child. Another positive impact of music therapy is also able to improve sleep quality, i.e. $80 \%$ of pregnant women have better quality sleep. ${ }^{[13]}$

Table 3 The Effectiveness of Music Therapy on Anxiety of Pregnant Women in the Third Trimester

\begin{tabular}{|c|c|c|c|c|c|c|}
\hline & & $\mathbf{N}$ & $\begin{array}{c}\text { Mea } \\
\text { n } \\
\text { Ran } \\
\mathbf{k}\end{array}$ & $\begin{array}{c}\text { Sum } \\
\text { of } \\
\text { Ran } \\
\text { ks }\end{array}$ & $\mathbf{Z}$ & $\begin{array}{c}\text { Asym } \\
\text { p. Sig. } \\
\text { (2- } \\
\text { tailed) }\end{array}$ \\
\hline $\begin{array}{l}\text { Inter } \\
\text { venti } \\
\text { on - } \\
\text { Anxi } \\
\text { ety }\end{array}$ & $\begin{array}{l}\text { Nega } \\
\text { tive } \\
\text { Rank } \\
\text { s } \\
\text { Posit } \\
\text { ive } \\
\text { Rank } \\
\text { s } \\
\text { Ties } \\
\text { Total }\end{array}$ & $\begin{array}{l}2^{c} \\
30\end{array}$ & $\begin{array}{c}15.5 \\
9\end{array}$ & $\begin{array}{c}343 . \\
0\end{array}$ & $\begin{array}{c}- \\
3.19 \\
3^{\mathrm{b}}\end{array}$ & 0.001 \\
\hline
\end{tabular}

Based on table 3, it is known that the Wilcoxon test results showed that there were differences in anxiety on pregnant women in the third trimester before and after being given music therapy with a p-value of $0.001<0.05$. There was a decrease in anxiety score from 9.53 to 4.47 , which is a mild anxiety category. Yu-Hsiang Liu in his research "Effects Of Music Listening On Stress, Anxiety, and Sleep Quality for SleepDisturbed Pregnant Women" stated that listening to music for two weeks could reduce stress, anxiety, and produce better sleep quality for pregnant women who are having a sleep disorder. Music stimulation captured by the five senses will be transmitted to the brain, which will affect the autonomic nervous system reducing the work of the sympathetic nerves and increasing the work of the parasympathetic system. So music can make people feel more relaxed and comfortable. Also, music stimulation in the brain affects the work of the anterior pituitary to suppress the production of catecholamines or stress hormones. (7) Likewise, with instrumental music therapy, it was found that the effect of music on reducing the anxiety of pregnant women. (11) Although the research of Mo Oh, Kim YJ. et al. stated that there were no significant differences in music interventions on systolic blood pressure and heart rate between the two groups, but music therapy was effective in reducing anxiety and stress in pregnancy. ${ }^{[4]}$

Anxiety in pregnant women stimulates the release of stress hormones such as ACTH (Adreno CorticoTropin Adrenal), cortisol, catecholamines. These hormones make the blood vessels undergo systemic vasoconstriction, including contraction of blood vessels in the uterus and placenta. This condition disrupts the supply of oxygen to the fetus so that the fetus could be distress. Lack of oxygen supply to the uterine muscles makes uterine contractions weak and make labour long. (14) This condition is very unfavourable for the mother. Music played to the mother can overcome this problem. Music vibrations with 60 beats/minute are the same as brain nerve vibrations, so they can stimulate the brain nerves to swing. These tones can enhance and stimulate the release of $\beta$-Endorphin. $\beta$-Endorphin is a compound produced by the pituitary gland consisting of 31 amino acids, the result of the division of ProopioMelanoCortin (POMC). $\beta-$ Endorphin can produce analgesics that prevent nerve cells from releasing pain signals. The more ß-Endorphin is released, the mother becomes calmer and happier. Stress hormones decrease influence decreasing of anxiety level. Music can provide energy and commands through the rhythm so that music with the 
right tempo can help women regulate breathing so that in addition to reducing anxiety can also reduce the pain felt by patients. ${ }^{[15]}$

\section{Conclusion}

Anxious scores on pregnant women in the third trimester before being given music was 9.53. Whereas after being given music, therapy dropped to 4.47 . There is a difference in the level of anxiety before and after therapy (p-value $0.001<0.05$ ). Music therapy is effective for reducing anxiety on pregnant women in the third trimester. AUthors recommend using music therapy in the care for anxiety in the third trimester of pregnancy.

\section{Acknowledgement}

All authors were grateful to the Directorate of Research and Community Service (DP2M) of Higher Education, Institute of Research and Community Service (LPPM) of Ngudi Waluyo University.

\section{References}

[1] Tyastuti, Siti, wahyuningsih, Puji.AsuhanKehamilan.

Kemenkes. 2016.

[2] Analia \& Moekroni R.Pengaruh Pemberian Terapi Musik Klasik dalam Menurunkan Tingkat Kecemasan Ibu Hamil Menjelang Persalinan. Majority. 2016. Volume 5.Nomor 1.Februari.

[3] Anggit, Ratnawati E. Perbedaan musik klasik mozart dan instrumental modern kitaro terhadap tingkat kecemasan ibu hamil primigravida trimester III dalam menghadapi persalinan. Stikes Bhamada [internet]. 2014. http://www.

stikesbhamada.ac.id/ojs/index.php/ jitk/article/viewFile/27/28.

[4] Asmara, Maya Shella, dkk.Efektifitas Hipnoterapi dan Terapi Musik Klasik terhadap KecemasanIbuHamilResiko Tinggi di PuskesmasMagelang Selatan. 2017.
[5] Salafas E,Anisa R,Rusita VI. EfektifitasHypno-EFT

danpernafasan yoga untukmenurunkankecemasanIbuha mil di BPM Ny. Sri Kustinah,Bidan Prada: Jurnal Bidan Prada: Jurnal Ilmiah Kebidanan. 2016. Vol. 7 No. 2 Edisi Desember 2016, hlm. 84-94

[6] Hawari, D. Manajemen Stres Cemas dan Depresi. Jakarta: Balai Penerbit FKUI. 2011.

[7] Liu, Yu-Hsiang, et.al.Effect of music listening on stres, anxiety and sleep quality for sleepdisturbed preganant woment. 2014.

https://doi.org/10.1080/03630242. 2015.1088116

[8] Campbell, D. Efek Mozart. Alihbahasa: Hermaya. Jakarta: PT. GramediaPustakaUtama. 2006.

[9] Safari, Triantoro dan Saputra, Nofrans Eka.Manajemen Emosi. Jakarta : Bumi Aksara. 2012.

[10] Dayyana. S, et.al. Effectiveness Of Music Therapy On Anxiety And B-Endorphin Levels In Primigravida During The Third Stage Of Pregnancy. 2017.

[11] Meihartati, T, dkk. Pengaruh Teknik Relaksasi Musik Instrumental Terhadap Penurunan Tingkat Kecemasan Ibu Hamil Trimester III. Jurnal Darul Azhar. 2018. Vol 6, No.1 Agustus 2018 Januari 2019, Hal : $76-84$.

[12] Kecemasan Ibu Hamil Resiko Tinggi di Puskesmas Magelang Selatan.University Research Colloquium. ISSN 24079189. 2017.

[13] Rahayu, Inggrid. Pengaruh Terapi Musik Klasik Terhadap Kualitas Tidur Pada Ibu Hamil Trimester III Di Desa Margahayu Wilayah Kerja Puskesmas Leuwigoong Kabupaten Garut Tahun 2015. 2015.

[14] Pieter, Herry Zan, Lumongga Lubis.Pengantar Psikologi untuk Kebidanan. Jakarta: Kencana. 2010. 
[15] S Wahida, Nooryanto M, Andarini S. Terapi murotal Alqur'an surat arrahman meningkatkan kadar ß-endorphin dan menurunkan intensitas nyeri pada ibu bersalin kala I fase aktif. Universitas Brawijaya. 2015.Jurnal IKESMA. http://www.ub.ac.id.http://www.ju rnal.unej.ac.id/index.php/IKESM A/article/download/1098/871. 